\title{
HUBUNGAN INDEKS MASSA TUBUH (IMT) DENGAN RESPON KLINIS KEMORADIASI PASIEN KANKER SERVIKS STADIUM III DI RSUD Dr. SAIFUL ANWAR MALANG
}

\author{
Adys Werestandina*, Tatit Nurseta**® ${ }^{*}$ Fajar Ari Nugroho ${ }^{* \star *}$
}

\begin{abstract}
Abstrak
Kanker serviks merupakan gangguan yang terjadi pada sel somatik, ketika perubahan materi genetik menyebabkan sel normal berperilaku abnormal. Pada kanker serviks stadium III dilakukan pengobatan standar yaitu kemoradiasi. Respons klinis kemoradiasi dipengaruhi beberapa faktor salah satunya yaitu indeks massa tubuh (IMT). Penelitian ini bertujuan mengetahui hubungan indeks massa tubuh dengan respons klinis kemoradiasi pasien kanker serviks stadium III. Desain penelitian yaitu observasi dengan pendekatan cohort retrospective menggunakan data rekam medis pasien kanker serviks di RSUD dr. Saiful Anwar Malang. Data rekam medis yang digunakan sebanyak 27 pasien. Analisis data dengan uji korelasi Spearman's rho, didapatkan hubungan yang signifikan antara indeks massa tubuh terhadap respons klinis kemoradiasi dengan nilai $P=0,001(0.001<\alpha=0.05)$. Uji hubungan keeratan dengan correlation coefficient didapatkan hasil $-0,594$, yang berarti bahwa ada hubungan yang kuat namun berkebalikan antara IMT dengan respons klinis.
\end{abstract}

Kata kunci: IMT, kanker serviks, kemoradiasi.

\section{RELATIONSHIP OF BODY MASS INDEX WITH CLINICAL RESPONSE TO CHEMORADIATION ON STAGE III OF CERVICAL CANCER PATIENTS AT DR. SAIFUL ANWAR PUBLIC HOSPITAL MALANG}

\begin{abstract}
Abstarct
Cervical cancer is a disorder that occurs in somatic cells due to genetic material alteration causes normal cells to behave abnormally. On stage III of cervical cancer standard treatment such as chemo-radiation is required. The response of this therapy is influenced by several factors, one of them is body mass index (BMI). This study aimed was to determine the relationship of body mass index with clinical response to chemo-radiation on stage III of cervical cancer patients at Dr. Saiful Anwar Public Hospital. It was observational study with cohort retrospective using medical record of cervical cancer patients at Dr. Saiful Anwar Public Hospital. The medical record data used was 27 patients. The data were analyzed by Spearman's rho test. The result showed that there was a significant correlation between BMI and clinical response to chemo-radiation with p-Value $0.001(0.001<$ $\alpha=0.05$ ). Correlation coefficient test result showed -0.594 , it means there was strong but inverse correlation between $\mathrm{BMI}$ and clinical response to chemo-radiation.
\end{abstract}

Keywords: BMI, cervical cancer, chemoradiation.

* Program Studi Kebidanan, FKUB

** Lab Obstetri dan Ginekologi, RSSA-FKUB

${ }^{* * *}$ Program Studi IImu Gizi, FKUB

\tatitnurseta@yahoo.com 


\section{Pendahuluan}

Kanker atau dalam bahasa medis disebut karsinoma merupakan penyakit yang ditandai oleh pertumbuhan dan perkembangan sel-sel yang tidak terkontrol. ${ }^{1} \mathrm{Di}$ Indonesia, kanker serviks merupakan kanker dengan penderita terbanyak pada perempuan. ${ }^{2}$ Salah satu pengobatan kanker serviks adalah kemoradiasi yaitu kombinasi kemoterapi dan radiasi untuk pasien kanker serviks stadium lanjut. ${ }^{3}$

Respons klinis yang dihasilkan dari terapi dipengaruhi oleh status gizi melalui pengukuran indeks massa tubuh. ${ }^{4}$ Malnutrisi dan penampilan tubuh yang kurus atau kaheksia merupakan masalah yang umum dijumpai pada pasien kanker yang akan berdampak pada kualitas hidup dan survival. Malnutrisi pada pasien kanker akan berdampak buruk pada hasil terapi antikanker serta dapat meningkatkan morbiditas dan mortalitas dibandingkan pasien dengan status gizi baik ${ }^{5}$.

Indeks massa tubuh merupakan parameter untuk memantau status gizi orang dewasa khususnya yang berkaitan dengan kekurangan dan kelebihan berat badan, dengan mempertahankan berat badan normal memungkinkan seseorang dapat mencapai usia harapan hidup yang lebih panjang. ${ }^{6}$

Data mengenai status gizi yang dilihat melalui parameter IMT pada penderita kanker serviks sangat dibutuhkan untuk menunjang pemberian terapi yang dan menentukan prognosis yang lebih baik.

Penelitian ini bertujuan untuk membuktikan hubungan indeks massa tubuh dengan respons klinis kemoradiasi pasien kanker serviks stadium III di RSUD Dr. Saiful Anwar Malang. Hasil penelitian ini bermanfaat untuk memberikan informasi mengenai IMT dengan respons klinis kemoradiasi yang dihasilkan, yang selanjutnya dapat menjadi pertimbangan dalam memberikan terapi dan menurunkan angka morbiditas dan mortalitas pada pasien kanker serviks.

\section{Bahan dan Metode}

Penelitian ini menggunakan studi observasional analitik dengan pendekatan cohort retrospective. Populasi dalam penelitian ini adalah seluruh wanita yang menderita kanker serviks yang pernah dirawat di RSUD dr. Saiful Anwar pada tahun 2009-2013. Pengambilan sampel menggunakan metode nonprobability consecutive sampling dan didapatkan sampel sebesar 27 pasien. Pengambilan data dalam penelitian ini menggunakan data sekunder rekam medis pasien kanker serviks stadium III yang memenuhi kriteria inklusi dan eksklusi.

Analisis data dalam penelitian ini menggunakan uji korelasi Spearman's rho untuk mengetahui ada tidaknya hubungan antara IMT dengan respons klinis. Analisis correlation coefficient digunakan untuk mengetahui keeratan hubungan antara IMT dengan respon klinis.

\section{Hasil}

Sampel pada penelitian ini diambil dari rekam medis wanita yang menderita kanker serviks stadium III dan mendapatkan kemoradiasi di RSUD Dr. Saiful Anwar Malang periode 2012-2013 dengan jumlah 87 orang, namun setelah melalui proses inklusi didapatkan 27 sampel yang memenuhi kriteria.

\section{Analisis Univariat}

Pada Tabel 1, ditampilkan indeks massa tubuh dan persentasenya. Pengukuran IMT dilakukan sebelum kemoradiasi dan tidak dilakukan pengukuran lagi setelah kemoradiasi selesai. Pengukuran IMT ini berdasarkan BB dan TB yang ada pada lembar rekam medis yang dituliskan oleh dokter atau hasil laboratorium. Respons klinis diukur setelah kemoradiasi dengan melihat regresi tumor (Tabel 2). 
Tabel 1. Indeks massa tubuh

\begin{tabular}{lcc}
\hline $\begin{array}{c}\text { Indeks Massa } \\
\text { Tubuh }\end{array}$ & $\begin{array}{c}\text { Frek } \\
\text { uensi }\end{array}$ & Persen $(\%)$ \\
\hline Underweight & 4 & 14,8 \\
\hline Normal & 18 & 66,7 \\
\hline Overweight & 5 & 18,5 \\
\hline Total & 27 & 100 \\
\hline
\end{tabular}

Tabel 2. Respons klinis kemoradiasi

\begin{tabular}{ccc}
\hline Respons klinis kemoradiasi & Frekuensi & Persen (\%) \\
\hline Komplit & 3 & 11,1 \\
\hline Parsial & 8 & 29,6 \\
\hline Stabil & 3 & 11,1 \\
\hline Progresif & 13 & 48,1 \\
\hline Total & 27 & 100
\end{tabular}

\section{Uji Prasyarat Parametrik}

Penelitian ini menggunakan uji Kolmogorov-Smirnov untuk mengetahui apakah data sampel terdistribusi normal atau tidak. Hasil uji Kolmogorov-Smirnov pada data IMT menunjukkan nilai $p=0,867>\propto=0,05$, sehingga data terdistribusi normal. Namun, uji Kolmogorov-Smirnov pada data respons klinis yang telah ditransformasi dengan MSI menunjukkan bahwa data respons klinis tidak terdistribusi normal dengan $p=0,015<\alpha=$ 0,05 .

\section{Analisis Bivariat}

Analisis yang digunakan adalah analisis nonparametrik dengan uji korelasi Spearman's rho karena data respons klinis tidak memenuhi syarat untuk statistik parametrik.

Tabel 3. Tabulasi silang indeks massa tubuh dengan respons klinis kemoradiasi

\begin{tabular}{lccccc}
\hline \multirow{2}{*}{ IMT } & \multicolumn{4}{c}{ Respons Klinis } & Total \\
\cline { 2 - 5 } & Komplit & Parsial & Stabil & Progresif & \\
\hline Underweight & $0(0 \%)$ & $0(0 \%)$ & $1(25 \%)$ & $3(75 \%)$ & $4(14,8 \%)$ \\
\hline Normal & $0(0 \%)$ & $6(33,3 \%)$ & $2(11,1 \%)$ & $10(55,6 \%)$ & $18(66,7 \%)$ \\
\hline Overweight & $3(60 \%)$ & $2(40 \%)$ & $0(0 \%)$ & $0(0 \%)$ & $5(18,5 \%)$ \\
\hline Total & $3(11,1 \%)$ & $8(29,6 \%)$ & $3(11,1 \%)$ & $13(48,1 \%)$ & $27(100 \%)$ \\
\hline
\end{tabular}

Tabel 4. Hasil uji korelasi Spearman's rho

\begin{tabular}{cc}
\hline & Sig. (2-tailed) \\
\hline Uji Spearman's Rho & 0,001 \\
\hline Correlation Coefficient & $-0,594$ \\
\hline
\end{tabular}

Uji statistik di atas menunjukkan hubungan negatif yang signifikan antara IMT dan respons klinis kemoradiasi dengan $p$-Value $0,001<a=$ 0,05 dan nilai correlation coefficient $=-0.594$.

\section{Pembahasan}

Berdasarkan hasil observasi rekam medis pasien di RSUD dr. Saiful Anwar Malang menunjukkan responden dengan IMT underweight menghasilkan respons klinis stabil sebesar $25 \%$ dan respons klinis progresif sebesar $75 \%$. Respons klinis didominasi oleh progresif dikarenakan pada pasien dengan IMT underweight terjadi ketidakseimbangan asupan protein dan energi yang menyebabkan perubahan metabolisme yang berdampak buruk pada hasil terapi. ${ }^{5}$ 
Responden dengan IMT normal menunjukkan respons klinis progresif sebesar $55,6 \%, 33,3 \%$ respons klinis parsial dan $11,1 \%$ respons klinis stabil. Respons klinis yang dihasilkan didominasi oleh progresif. Kemungkinan hal ini dikarenakan pada pasien dengan IMT normal memiliki interval penurunan BB yang besar, walaupun nilai IMT masih tergolong normal. Selanjutnya responden dengan IMT overweight menghasilkan respons klinis komplit sebesar $60 \%$ dan respons klinis parsial sebesar $40 \%$. Pada IMT overweight menghasilkan penyebaran respons klinis yang lebih baik yaitu komplit dan parsial diikuti IMT yang normal dengan penyebaran yang lebih bervariasi meskipun respons progresif lebih dominan. Sementara pada IMT underweight penyebaran respons klinisnya lebih jelas dengan variasi lebih sedikit yang juga didominasi oleh progresif.

Respons klinis progresif mempunyai persentase terbesar pada hampir semua kelompok IMT. Kemungkinan hal ini karena adanya faktor lain yang juga berpengaruh terhadap respons klinis yang tidak diteliti oleh peneliti seperti stadium IIIA atau IIIB yang secara teori stadium IIIB mempunyai prognosis yang lebih buruk dibandingkan stadium IIIA.

Hasil ini sesuai dengan teori bahwa gizi yang optimal dapat memberikan beberapa manfaat pada proses penyembuhan. ${ }^{7}$ Sehingga dengan indeks massa tubuh yang optimal akan lebih baik respons klinisnya dibandingkan dengan hasil respons klinis indeks massa tubuh underweight.

Hasil penelitian ini juga sependapat dengan Mirzana (2008) bahwa malnutrisi dan asupan energi protein yang tidak adekuat pada kanker serviks berhubungan dengan hasil kemoradiasi dan kualitas hidup pasien. Penelitian ini juga menyebutkan bahwa IMT yang rendah (IMT <17) dan asupan energi dan protein yang rendah dan tidak sesuai kebutuhan dimiliki oleh pasien dengan stadium IIIB. Hal ini dikarenakan oleh efek samping kemoradiasi yang menyebabkan kaheksia kanker. ${ }^{8}$

\section{Kesimpulan}

Berdasarkan hasil penelitian didapatkan bahwa persentase IMT normal sebesar $66,7 \%$, kelompok IMT overweight sebesar $18,6 \%$ dan kelompok underweight sebesar $14,8 \%$. Persentase respons klinis progresif sebesar $48,1 \%$, selanjutnya respons klinis parsial sebesar 29,6\%, respons klinis komplit sebesar $11,1 \%$, dan respons klinis stabil sebesar $11,1 \%$. Ada hubungan yang signifikan antara indeks massa tubuh dengan respons klinis kemoradiasi $(p=0,001<0,05)$. Tingkat keeratan antara IMT dan respons klinis adalah kuat dan bersifat negatif yaitu ada hubungan yang berkebalikan antara IMT dengan respons klinis $(-0,594)$.

\section{Saran}

1. Diharapkan peneliti berikutnya dapat meneliti faktor-faktor lain yang dapat mempengaruhi respons klinis, misalnya stadium kanker, aktivitas fisik, usia dan tingkat konsumsi yang belum digunakan pada penelitian ini.

2. Diharapkan untuk penelitian selanjutnya menggunakan analisis cohort prospective untuk memperkecil bias informasi sehingga penelitian lebih akurat.

\section{Daftar Pustaka}

1. Price $S$ dan Wilson L. Patofisiologi: Konsep Klinis Proses-Proses Penyakit. Edisi ke-6. Jakarta: Penerbit EGC. 2005.

2. Rasjidi I. Deteksi Dini dan Pencegahan Kanker pada Wanita. Jakarta: Sagung Seto. 2009.

3. Torbe B, Falco M, Torbe A, Ciepiela P, Kurzaa R. Radiotheraphy Versus Radiochemotheraphy with Cisplatin in Treatment of Cervical Cancer. Medical Oncology. 2010: 27:1-8. 
4. Laky B, Janda M, Cleghorn G, Obermair A. Comparisson of Different Nutritional Assesments and Body Composition Measurement in Detecting Malnutrition among Gynecologic Cancer Patients. Am J Clin Nutr. 2008; 87:78-85.

5. Hariani R. Kecukupan Nutrisi pada Pasien Kanker. Indonesian Journal Of Cancer. 2007; 4:140-143.

6. Supariasa I. Bakri B, Fajar I. Penilaian Status Gizi. Jakarta: Penerbit EGC. 2002.
7. Zulkarnain AK. Perbedaan Indeks Massa Tubuh Pasien Ca Mammae Duktus Infilnfiltratif Sebelum dan Sesudah Mendapat Terapi Neoadjuvant. Skripsi. Semarang: Universitas Diponegoro. 2010.

8. Mirzana I. Asupan Energi, Protein dan Status Gizi pada Pasien Kanker Serviks dengan Terapi Kemoradiasi. Skripsi. Semarang: Universitas Diponegoro. 2008. 